\title{
Czym jest „Zachód” ?
}

\section{What is the "West"?}

\author{
Paulina Wandas \\ Instytut Językoznawstwa, Uniwersytet im. Adama Mickiewicza \\ al. Niepodległości 4, 61-874 Poznań \\ paulinawandas@wp.pl
}

\begin{abstract}
The prevailing majority of words demonstrate high level of uniformity due to their meaning and are related to things existing in reality. However, there is no doubt that lexicology knows words and wording that are highly ambiguous, elusive and there is a huge problem making out some kind of universal definition, acceptable for everyone. The West is one of them. The main aim of the article What is the West ? was to present the range of definitional conceptions and to indicate an extraordinary capacity of meanings to this notion. The article does not deliver the synonymous, ready - made answer to the question of the title but set the readers thinking and make them come to personal conclusions.
\end{abstract}

We współczesnych stosunkach międzynarodowych trudno znaleźć drugie określenie, które byłoby równie niejednoznaczne, co pojęcie "Zachód”. Można by ująć to w postaci krótkiego stwierdzenia: „ilu badaczy, tyleż koncepcji”. Czymże bowiem jest ów „Zachód”? Kręgiem cywilizacyjnym, wirtualną rzeczywistością McŚwiata, a może jedynie pewną konstrukcją myślową, nie zaś bytem realnie istniejącym?

W pierwszej kolejności warto zaprezentować teorię amerykańskiego politologa Samuela Huntingtona. W jego przekonaniu „Zachód” to jeden $\mathrm{z}$ ośmiu kręgów cywilizacyjnych ( kulturowych ), na który geograficznie składają się Europa, Ameryka Północna i inne obszary zasiedlone przez Europejczyków, takie jak Australia i Nowa Zelandia. „Jest to krąg zachodniego chrześcijaństwa, katolicyzmu i protestantyzmu. Obejmuje państwa o bardzo wysokim poziomie rozwoju gospodarczego, dużym potencjale militarnym, słabnącym przyroście naturalnym"1. Autor podkreśla, iż termin „Zachód” powszechnie używany jest dziś jako określenie tego, co niegdyś nazywano zachodnim chrześcijaństwem. Jest to więc jedyna cywilizacja, która miano swoje wzięła od kierunku wskazywanego przez kompas, nie zaś od nazwy konkretnego narodu, religii czy obszaru geograficznego ${ }^{2}$.

\footnotetext{
${ }^{1}$ Stosunki międzynarodowe, pod red. W. Malendowski, Cz. Mojsiewicz, Wrocław 2004, s.86.

${ }^{2}$ S. P. Huntington, Zderzenie cywilizacji i nowy ksztalt ładu światowego, Warszawa 2003, s. 58.
} 
Zachodzi jednak pytanie: od czego na zachód? Odpowiadając na nie, widać jak bardzo pejoratywne jest to określenie. Bowiem pierwotnie „Zachodem” nazywana była zachodnia i wschodnia część Eurazji, lecz z amerykańskiego punktu widzenia Daleki Wschód jest Dalekim Zachodem, zaś dla Chińczyków na przykład „Zachód” przez większą część ich historii oznaczał Indie.

Samuel Huntington wskazuje również na to, iż tak zwany „wielocywilizacyjny Wolny Świat" z czasów Zimnej Wojny przekształcił się w nowe ugrupowanie, pokrywające się w mniejszym lub większym stopniu $\mathrm{z}$ obszarem cywilizacji zachodniej. W ramach tegoż ugrupowania ma miejsce proces tworzenia więzi, opartych między innymi na określaniu zasad przynależności do zachodnich organizacji międzynarodowych. Tutaj pojawia się jednak kolejne pytanie. Gdzie kończy się „, Zachód” ? S.Huntington za punkt graniczny uznaje tak zwaną wielką linię historyczna, oddzielającą wyznawców zachodniego chrześcijaństwa od ludów muzułmańskich i prawosławnych. „Linia ta pochodzi z czasów podziału cesarstwa rzymskiego w IV wieku i utworzenia Świętego Cesarstwa Rzymskiego w X wieku. Przebiega mniej więcej w tym samym miejscu od co najmniej pięciuset lat. Od północy biegnie wzdłuż dzisiejszej granicy między Finlandią, a Rosją, następnie wzdłuż granic państw bałtyckich z Rosja, przez zachodnią Białoruś, przecina Ukrainę, dzieląc ją na unicki zachód i prawosławny wschód, potem Rumunię, gdzie oddziela Transylwanię z katolicką węgierską ludnością od reszty kraju. W byłej Jugosławii biegnie wzdłuż granicy między Słowenią i Chorwacją, a pozostałymi republikami. Na Bałkanach pokrywa się z historyczną granicą między Austro-Węgrami, a Imperium Osmańskim"”3. Jest to kulturowa granica Europy, polityczna i gospodarcza rubież Europy i Zachodu.

„Zachód” zgodnie z huntingtonowską koncepcją charakteryzuje się także dwoma specyficznymi cechami. Sa to mianowicie :

> -wielość języków ( tym właśnie cywilizacja zachodnia różni się od pozostałych, gdzie w zasadzie panuje jeden język : chiński, arabski, rosyjski itp.);

$>$ dominacja indywidualizmu ( cecha ta szczególnie uwidacznia się w porównaniu z cywilizacjami azjatyckimi: chińską, japońską, gdzie wręcz swoistym dogmatem, obejmującym wszystkie sfery życia, jest kolektywizm).

W kontekście geograficznego ujęcia cywilizacji zachodniej, warto zaprezentować również podejście geopolityczne do problematyki zdefiniowania „Zachodu”. Na wstępie istotnym wydaje się ukazanie, czym jest geopolityka. Otóż z grubsza rzecz ujmując, jest to pewna refleksja, metoda badawcza, pokazująca ,wpływ czynników geograficznych, zarówno fizycznych, jak i ludzkich na analizy, wybory i działania polityczne podejmowane w stosunku do innych podmiotów politycznych działających na tym samym terytorium". Czy więc geopolitycznie Stany Zjednoczone i Europa stanowią jedność i wzajemnie się uzupełniają, czy może każdy $\mathrm{z}$ wymienionych powyżej podmiotów jest odrębnym „aktorem” sceny międzynarodowej? Jeśli przyjąć pierwszy wariant, a więc monolityczność, amerykańsko - europejskie „rodzeństwo” ma wspólne interesy, synergicznie uzupełniające się zasoby militarne, technologiczne, surowcowe oraz wspólną wizję przyszłości. Natomiast w wypadku prawdziwości drugiej koncepcji, opowiadającej się za odrębnością tychże dwóch bytów, można rozpatrywać dla każdego z nich różne scenariusze. Ideę tę najlepiej ukaże pytanie: Czym będzie „Zachód” w wydaniu europejskim, czym zaś w amerykańskim wydaniu? Dla Stanów Zjednoczonych przewiduje się następujące trzy scenariusze :

\footnotetext{
${ }^{3}$ Ibidem, s.265.

${ }^{4}$ C. Jean, Geopolityka, Wrocław 2003, s. 45.
} 
$>$ po pierwsze, powstanie ,półkuli zachodniej” czyli sojuszu Ameryki Północnej i Południowej;

$>$ po drugie, Stany Zjednoczone jako istotna część geopolitycznego tworu, zwanego G8;

$>$ scenariusz ostatni zaś optuje za powstaniem Pax Americana czyli Stany Zjednoczone występujące w roli „światowego żandarma”.

Jeśli chodzi o scenariusze dla Europy, jest ich znacznie więcej. Po pierwsze, „Europa obywateli" czyli ziszczenie marzeń europejskich federalistów. Jest to idea dość utopijna, w kontekście nadal silnej roli państwa narodowego w Europie. Po drugie, „Europa ojczyzn” czyli z grubsza rzecz ujmując opis stanu obecnego. Po trzecie w końcu „Europa regionów", a więc istnienie ośrodka napędowego i peryferii. Może zaś prawdziwą okaże się idea „Europy handlarzy”, zredukowanej jedynie do unii celnej lub strefy wolnego handlu bez zjednoczenia politycznego, czy gospodarczego. Jeszcze jeden z istotnych scenariuszy zakłada fragmentaryzację, bałkanizację, a więc rozbicie Europy nie tyle na państwa, ale wręcz na regiony i inne mniejsze jednostki terytorialne ${ }^{6}$.

Kolejnym badaczem, który zajmował się problematyką świata zachodniego jest Benjamin Barber, autor koncepcji tzw. McŚwiata jako pewnej rzeczywistości wirtualnej, stworzonej przez wszechpotężne sieci wysoko rozwiniętych technik informacyjnych i płynne ponadnarodowe rynki ${ }^{7}$. Ujmuje on „Zachód" bardziej w kategoriach ekonomicznych, jako swoisty rynek, którego podstawą są niczym nie zakłócane stosunki wymiany między indywidualnymi konsumentami, a indywidualnymi producentami. Czy więc „Zachód” to światowe „plemię konsumentów” i rządzących nimi ponadnarodowych korporacji? B. Barber zauważa, iż tożsamość rynkowa to tylko jeden „krnąbrny” element całej tożsamości człowieka, na którą składa się również aspekt etniczny i obywatelski, te zaś mogą rywalizować czy nawet pozostawać w konflikcie $\mathrm{z}$ tożsamością określaną przez rynek $^{8}$. Daje więc on nadzieję ,ludziom Zachodu”, iż nie są jedynie „marionetkami” w rękach transnarodowych ,gigantów ekonomicznych". Zwraca także uwage na to, iż w ekonomicznym systemie McŚwiata surowce i towary ustępują powoli miejsca nowej dziedzinie działalności, określanej przez autora jako ,inforozrywkowy telesektor”. Za jego sprawą ma miejsce reorganizacja stosunków między państwami oraz określenie na nowo ekonomicznych realiów McŚwiata. Najważniejszym towarem staje się więc tzw. „, towar niematerialny".

B. Barber wskazuje również na pewną integralną cechę McŚwiata, będącą jednocześnie jego ciemną stroną, mianowicie na niesprawiedliwość. Przekonuje, że nawet gdy ponadnarodowe rynki zajmą miejsce państw, ludzie pozostaną producentami i konsumentami. Zaś ze względu na nierównomierne rozmieszczenie światowych zasobów bogactw naturalnych, McŚwiat dla jednych będzie ,placem zabaw”, podczas gdy dla drugich „cmentarzem”. W ujęciu tegoż autora McŚwiat to także pewien swoisty styl życia, z gruntu amerykański, lecz potencjalnie ma on charakter globalny. „Jest wielce kuszący, młodzieńczy i zamożny jak yuppie, po kowbojsku nieokrzesany, czarowny jak Hollywood, nieskrępowany niczym rajski ogród, wyrozumiały dla błędów, wyczulony na problemy społeczne, politycznie poprawny, przepojony atmosfera wielkiego centrum

\footnotetext{
5 Ibidem, s. $284-286$.

6 Ibidem, s. $292-295$.

${ }^{7}$ B. Barber, Dżihad kontra McŚwiat, Warszawa 2004, s.35.

8 Ibidem, s.41.
} 
handlowego(...)" ${ }^{\text {"M }}$ McŚwiat więc to wytwór kultury masowej, napędzanej przez komercję, za którego myśl przewodnią można by uznać hasło, nawiązujące do „ideałów komunistycznych” - „Konsumenci wszystkich krajów łączcie się”.

Kultura McŚwiata jest wypaczona i skomercjalizowana, lecz mimo wszystko jest kultura, a więc zbiorem pewnych symboli i wyobrażeń. Jakie elementy jednak w największej mierze tworza, to co autor nazywa McŚwiatem? Można by wskazać, za B. Barberem, na trzy takie składniki :

$>$ hollyworld, czyli ideologia McŚwiata;

$>$ telewizja i MTV;

$>$ teleliteratura i parki tematyczne.

McŚwiat stanowi więc jedno ogromne przedsiębiorstwo, na które składają się:

$>$ domy towarowe;

$>$ multipleksy;

$>$ parki tematyczne;

$>$ stadiony sportowe;

$>$ sieci restauracji szybkiej obsługi;

$>$ telewizja.

Należałoby jednak również zastanowić się, czy pojęcia „Zachód" nie można rozpatrywać w kategoriach psychologicznych. W takim kontekście pojawia się koncepcja Oswalda Spenglera, ujmująca „Zachód” jako tzw. kulturę faustowską. Kultura ta zaś jest swoistą konstrukcją psychiczna, charakterystyczną dla człowieka zachodniej cywilizacji. „Zachód” w takim ujęciu stanowiłby więc pewną wspólnotę duchową, zbiór jednostek obdarzonych podobnymi właściwościami psychicznymi, mającymi swe odzwierciedlenie w podejmowanych działaniach i zachowaniu.

Prasymbolem kultury faustowskiej jest nieograniczona przestrzeń. Sam prasymbol zaś stanowi logos duszy kultury, najbardziej bezpośrednie przeświadczenie tego, co metafizyczne, nie urzeczywistnia się bezpośrednio, lecz tkwi we wszystkich realizacjach symbolicznych ${ }^{10}$. Przestrzeń jako symbol zachodniej cywilizacji zawiera w sobie bardzo wiele informacji na temat umysłowości człowieka Zachodu. Wskazuje na jego otwartość w kontaktach interpersonalnych, ciekawość świata, mobilność, nie zamykanie się w obrębie własnego, dobrze znanego otoczenia, lecz chęć poznawania tego, co nowe, a więc i intrygujące. O.Spengler przyrównuje także człowieka cywilizacji zachodniej do Fausta, bohatera poematu filozoficznego Johanna Wolfganga Goethego. Podkreśla, iż tak jak on przedstawiciele świata Zachodu są nienasyceni, nieukojeni, niespokojnie ku czemuś dążący. Autor tworzy przygnębiający i zmuszający do refleksji portret. Mówi bowiem, iż „ludzie Zachodu” uznają szczęście chwili za godne wzgardy, priorytetem jest dla nich czyn, aktywna postawa życiowa. W skrajnej postaci uważają oni wręcz życie za godne uwagi , tylko wówczas, gdy jest działaniem.

Człowiek faustowski nieustannie „prze” w dal, co objawia się we wszystkich dziedzinach życia. Osoba taka pragnie wciąż rozwijać się pod względem intelektualnym, jak i materialnym, w sensie gromadzenia coraz większej liczby dóbr. Jednak takie podejście do życia nie pozostaje bez wpływu na sferę duchowości ludzkiej. O.Spengler wskazuje na bezgraniczną samotność jako „ ojczyznę duszy faustowskiej”. Ujmuje to w następujących słowach : „niewypowiedziane poczucie opuszczenia - jest to faustowskie $i$ tylko faustowskie" $"$.

\footnotetext{
9 Ibidem, s.76.

10 O. Spengler, Zmierzch Zachodu.Zarys morfologii historii uniwersalnej., Warszawa 2001, s.9.

${ }^{11}$ Ibidem, s. 127.
} 
Kultura faustowska to również kultura woli, podkreślająca znaczenie aktywnego „Ja”, przepełnionego energią człowieka, chcącego przekształcać otaczającą go rzeczywistość. Przedstawiciel zachodniej kultury ma duszę odkrywcy. Charakteryzuje się pierwotną siłą woli, przenikliwością wizji. W świecie zachodniej cywilizacji dużą rolę odgrywa technika. Dzięki niej człowiek faustowski mógł zapanować nad naturą, ale jednocześnie nawet nie zauważył, kiedy maszyna stała się jego ,panem”.

Czy „Zachód” jest więc czymś głęboko zakodowanym w naszych umysłach, zbiorem charakterystycznych uwarunkowań psychologicznych, decydujących o tym, iż ludzie cywilizacji Zachodu odczuwają duchowe pokrewieństwo? Jeśli tak właśnie jest, człowiek Zachodu powinien $\mathrm{w}$ bezgranicznej przestrzeni częściej stykać się z przedstawicielami innych cywilizacji, a więc ludźmi obdarzonymi odmienną umysłowością. Bowiem wiele cech człowieka faustowskiego, wyżej wskazanych, negatywnie wpływa na jednostki tworzące cywilizację zachodnią. Zaś cywilizacja to suma jednostek, jej być albo nie być będzie więc zależało od przebudzenia się zachodnich społeczeństw z nieustannej gonitwy za ulotnymi, materialnymi dobrami tego świata.

Rosyjska myśl filozoficzna i polityczna również próbowała odpowiedzieć na pytanie, czym jest cywilizacja Zachodu i przewidzieć jej przyszłe losy. Egzystencjalista Mikołaj Bierdiajew ujmował „Zachód” jako najdoskonalszą cywilizację świata. Doskonałość ta jednak, w jego przekonaniu, przejawia się jedynie w sensie ekonomicznym. Cywilizacja zachodnia stworzyła bowiem system industrialno - kapitalistyczny, który oznacza jednak nie tylko poważny rozwój ekonomiczny, ale jawi się jako zjawisko destrukcyjne, niszczące ducha, Boga i świętości ${ }^{12}$. Autor stawia też radykalną tezę, iż na cywilizacji kapitalistycznej spoczywa odpowiedzialność za przestępstwo Bogobójstwa. Z drugiej strony jednak przyznaje, iż nie do końca nastąpiło odrzucenie religii, gdyż cywilizacja industrialno - kapitalistyczna gotowa jest uznać pragmatyczny pożytek z niej płynący. Stąd można wysnuć wniosek, iż na Zachodzie mamy do czynienia jedynie z kościołem pisanym przez małe k, w sensie pewnej struktury organizacyjnej, nie zaś Kościołem jako wspólnotą wiernych.

W takim ujęciu „Bóg Zachodu” ma być przede wszystkim pożyteczny dla rozwoju cywilizacji zachodniej i osiagania przez nią sukcesów. M. Bierdiajew uznaje jednak, iż taki Bóg nie jest Bogiem prawdziwym i dodaje, że Bóg religijnych objawień i symbolicznej kultury dawno już odszedł z cywilizacji kapitalistycznej i cywilizacja ta odeszła od Boga ${ }^{13}$. Autor podkreśla także mechaniczność cywilizacji Zachodu. Zauważa, iż rozwój techniki doprowadził do powstania sprzeczności między „zmechanizowanym światem kapitalistycznym", a istnieniem duchowości ludzkiego bytu. Mówi o tym, iż oderwanie gospodarki od ducha, uznanie ekonomii za podstawową zasadę życia, oddanie na usługi ekonomii całego życia, przekształcają ekonomię w fikcyjne królestwo ${ }^{14}$.Przyjmując taki punkt widzenia można powiedzieć, iż cywilizacja zachodnia to przede wszystkim pewna „przestrzeń gospodarcza”, gdzie główną zasadą postępowania jest maksymalizacja osiaganych korzyści, czyli szeroko pojmowany zysk. Jednak w takiej zmechanizowanej przestrzeni, której funkcjonowanie opiera się o zasady ekonomii, nie ma praktycznie miejsca na głęboką religijność i zatopienie się w duchowe rozważania. Człowiek Zachodu staje się więc areligijny, a jego racjonalizm i kalkulacyjne postrzeganie świata prowadzą do szeroko zakrojonej laicyzacji. W takim ujęciu „Zachód” jest więc doskonałą struktura ekonomiczną, lecz pozbawioną podstaw duchowych.

\footnotetext{
12 J. Sobczak, Zmierzch cywilizacji, Poznań 2002, s.28.

13 M. Bierdiajew, Sens historii. Filozofia losu człowieka, Kęty 2002, s.145.

${ }^{14}$ Ibidem, s 146
} 
Jeszcze inaczej kwestię, czym jest „Zachód”, postrzegał polski uczony Feliks Koneczny. Odwoływał się on mianowicie do dziedzictwa historycznego. Ujmował on więc cywilizację zachodnią jako cywilizację łacińską, będącą w wielu aspektach sukcesorem imperium rzymskiego. F.Koneczny wskazuje, iż opiera się ona na dwóch filarach : idei rzymskiego porządku społecznego i religii katolickiej ${ }^{15}$. Jej bazą jest rodzina monogamiczna. Z cywilizacji rzymskiej w największym stopniu przejęła dualizm prawny, a więc ścisłe rozgraniczenie sfery życia publicznego i prywatnego.

Wspomniany porządek społeczny cywilizacji Zachodu opiera się na pielęgnowaniu w życiu społecznym egzystencjalnych wartości bytu ludzkiego. Wartości te zaś, ze szczególnym uwzględnieniem dobra, usankcjonowane zostały przez religię i etykę katolicką. Etyka ta głosi m.in. konieczność dożywotniego, monogamicznego małżeństwa, przekazanie wymiaru sprawiedliwości w ręce sądownictwa publicznego czy niezawisłość kościoła od państwa. Zdaniem autora jednak, pomimo, iż religia katolicka jest bardzo ważnym elementem cywilizacji łacińskiej, cywilizacja ta ma charakter niesakralny. „Religia katolicka zachowuje dystans w stosunku do instytucji cywilizacji łacińskiej, stara

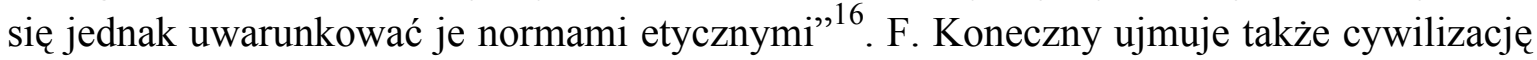
zachodnią jako cywilizację państw obywatelskich. Jego zdaniem powstanie państwa obywatelskiego w ramach „Zachodu” było konsekwencją zespolenia się trzech elementów, a mianowicie struktury społecznej i zasad prawnych, charakterystycznych dla cesarstwa rzymskiego z założeniami etyki katolickiej. W ten oto sposób wykształciło się państwo obywatelskie, będące „tworem kompleksowym”, tj. respektującym w pełni autonomię i prawa jednostki, z drugiej zaś strony opierającym się na społeczeństwie wolnych jednostek. Wszystkie wyżej wymienione cechy gwarantują cywilizacji zachodniej doskonałe wprost możliwości rozwojowe, zarówno wewnętrzne, jak i zewnętrzne. Autor podkreśla również, iż tylko w ramach cywilizacji łacińskiej doszło do wykształcenia się narodów, bowiem inne cywilizacje nie osiagnęły etapu emancypacji rodziny, a co za tym idzie społeczeństwa. „Naród będący „moralną nadbudową społeczeństwa” mógł powstać tylko w cywilizacji przesiąkniętej zasadami etycznymi - a taką jest jedynie cywilizacja łacińska"17.

Warto jednak zauważyć, iż w wyniku ścisłego powiązania cywilizacji łacińskiej z katolicyzmem, poza jej obrębem pozostawiono takie państwa, jak : Wielka Brytania, Szwecja, Holandia, Dania, także Niemcy, zaliczane przez F. Konecznego do cywilizacji bizantyjskiej. Ujęcie historyczne, zaprezentowane przez Feliksa Konecznego, wskazuje pomimo wszystko na bardzo ważny aspekt w życiu, egzystencji każdej cywilizacji. Mianowicie podkreśla rolę dokonań poprzednich „wielkich zbiorowości ludzkich”. Żadna bowiem $\mathrm{z}$ cywilizacji, w tym cywilizacja zachodnia, nie powstaje w próżni. Jest ściśle uwarunkowana historią, dziedzictwem kulturowym i intelektualnym poprzednich epok. I tak cywilizacja łacińska, w sferze ustrojowej bazuje na osiagnięciach starożytnego imperium rzymskiego, zaś w sferze kultury korzysta $\mathrm{z}$ dorobku helleńskiego.

Kończąc rozważania dotyczące problematyki czym jest „Zachód” warto zastanowić się czy stanowi on jedność, monolit. Jeżeli terminem „Zachód” obejmiemy, z grubsza rzecz ujmując, Stany Zjednoczone i Unię Europejską, zasadnym byłoby postawić pytanie czy nie są to odrębne byty, powiązane jedynie cienką nicią wspólnie wyznawanych wartości. Można by w takim razie ująć to zagadnienie w postaci pytania: co nas różni, co zaś łączy i czy jedność jest możliwa do osiagnnięcia?

\footnotetext{
15 J. Sobczak, op. cit., s 53.

16 Ibidem, s.54.

${ }^{17}$ Ibidem.
} 
Warto również zwrócić uwagę na to, iż monolityczność świata zachodniego, na chwilę obecną, pozostaje raczej w sferze postulatywnej. Jako przykład można tutaj wskazać koncepcję tzw. „atlantyckiej wspólnoty”, sformułowanej w listopadzie 1994 roku przez Malcolma Rifkinda. Uważał on, że czterema filarami „zjednoczenia euroatlantyckiego" byłyby : „obrona i bezpieczeństwo zapewniane przez NATO, wspólna wiara w rządy prawa i demokrację parlamentarna, liberalny kapitalizm i wolny handel oraz wspólne europejskie dziedzictwo kulturowe, wyrastające z Grecji i Rzymu, poprzez Renesans, po wspólne wartości, przekonania i cywilizacje naszego wieku" ${ }^{\prime 1}$. Czy tak naprawdę jednak zjednoczenie w różnorodności jest możliwe ? Unia Europejska bowiem sama w sobie nie stanowi nadal monolitu, interesy narodowe górują w wielu kwestiach nad interesem „regionalnej wspólnoty”. Stany Zjednoczone mają zaś problem z określeniem własnej tożsamości. Jeśli zaś zdewesternizują się, wówczas „Zachód”, jak podkreśla S.Huntington, „zostanie ograniczony do Europy i kilku rzadko zaludnionych krajów zamorskich, założonych przez europejskich osadników" "19.

Jak więc na chwilę obecną przedstawia się sytuacja ? Czy „Zachód” jest geopolityczną i cywilizacyjną jednością?

Na pewno można mówić o co najmniej siedmiu poważnych różnicach pomiędzy tzw. modelem amerykańskim, a europejskim. Są to :

$>$ pozycja religii;

$>$ rola państwa;

$>$ stopień akceptacji dla nierówności;

$>$ ochrona środowiska;

$>$ stosunek do swej narodowej tożsamości;

$>$ posiadanie i użytek, jaki robi się z broni;

$>$ kara śmierci ( szerzej prawa człowieka).

Są to w sumie różnice kulturowe, ekonomiczne, społeczne i różnice w podejściu do rozwiązywania problemów światowych. Jednak z drugiej strony, trzeba zauważyć istniejącą obiektywnie, pomiędzy Stanami Zjednoczonym, a Unią Europejską, współzależność interesów ekonomicznych i strategicznych. Poza tym mamy również do czynienia z sporą liczbą problemów, którym „Zachód” musi wspólnie stawić czoła.Na plan pierwszy wysuwa się na pewno kwestia zaopatrzenia w surowce energetyczne. Niektórzy eksperci zwracają nawet uwagę na to, iż nadciagga ,petroapokalipsa” : „Stoimy w obliczu nieuchronnego wstrząsu, który będzie rezultatem strukturalnego głodu naftowego"20. Kolejnym problemem jest demografia, ujemny przyrost naturalny w większości państw cywilizacji zachodniej. Dłuższe utrzymywanie się takiej „tendencji demograficznej” może wręcz doprowadzić do naturalnej, samoistnej zagłady „Zachodu”, gdzie kwestia monolityczności będzie już pozbawiona znaczenia. Istotną sprawą są też kontakty z, bądź co bądź, jednym z ważniejszych „graczy” na arenie międzynarodowej, a mianowicie z Rosją. Występowanie przez „Zachód” ze wspólnym stanowiskiem wobec Federacji Rosyjskiej mogłoby również przyczynić się do efektywniejszego uregulowania pierwszego $\mathrm{z}$ wymienionych problemów, a więc zaopatrzenia w surowce energetyczne. Jedność „Zachodu” będzie więc uwarunkowana „przeważeniem na szali zysków i strat” różnic, bądź problemów. Jak podkreśla przewodniczący Komisji Europejskiej Jose Manuel Barroso: „Świat potrzebuje ścisłego współdziałania USA i Unii. (...) Jeśli chcemy rozwiązywać problemy globalne, musimy współpracować. Spójrzmy na kwestię

\footnotetext{
18 S. P. Huntington, op. cit., s. 543.

${ }^{19}$ Ibidem, s. 541.

20 Ibidem, s.71.
} 
globalnego ocieplenia, problem terroryzmu, bezpieczeństwo energetyczne, zadłużenie Afryki - tych problemów nie rozwiążemy sami" ${ }^{21}$. Zwraca więc on uwagę na to, iż monolityczność świata zachodniego jest stanem pożądanym nie tylko z punktu widzenia Europy czy Stanów, lecz nade wszystko z perspektywy globalnej.

Jeżeli Stany Zjednoczone i Unia Europejska uznają, że wyżej wymienione kwestie problemowe i ich rozwiązanie stanowi żywotny interes obu stron, wówczas być może postarają się przejść nad różnicami do „porządku dziennego” i skupiając się na przykład na problemie energetycznym zbudują „wspólnotę ponad podziałami”. Robert Kagan przekonuje jednak, iż następowała i następuje nadal znaczna dyferencjacja na linii ,, Zachód” europejski - „Z Zachód” amerykański. Jego zdaniem przejawia się to najdobitniej w zakresie stosunku do używania siły jako instrumentu polityki zagranicznej. Na podstawie tegoż kryterium autor buduje ciekawą " metaforę planetarną", gdzie Europa utożsamiana jest $\mathrm{z}$ Wenus, natomiast Stany Zjednoczone $\mathrm{z}$ planetą Mars ${ }^{22}$. R.Kagan argumentuje, iż Europejczycy będąc Wenusjanami, przedkładają nad politykę siły i przymusu wariant negocjacyjny. Dla nich świat jest bardziej złożony, aniżeli dla marsjańskich Amerykanów, którzy dokonują automatycznego podziału na dobrych i złych, przyjaciół i wrogów. W marsjańskim mniemaniu wrogowie zagrażają wizji świata zgodnej z amerykańską percepcją, stąd należy użyć siły, aby zlikwidować ognisko zagrożenia. Z drugiej strony autor zwraca także uwagę na bardzo istotną kwestię, a mianowicie na powstanie tak zwanego , europejskiego ponowoczesnego raju"23. Eden ten , w którym panuje spokój i względna harmonia oraz skupienie się przede wszystkim na kwestiach gospodarczo - handlowych, został stworzony dzięki „, parasolowi ochronnemu” Stanów Zjednoczonych. Europejczycy zrzucili więc odpowiedzialność za bezpieczeństwo Wenus na wojowniczego Marsa, jedyne supermocarstwo, które dzięki swym zasobom jest predestynowane do przywódczej roli w świecie. Koncepcja monolityczności „Zachodu” może więc $z$ wielu względów być trudna do urzeczywistnienia, jednak jedność świata zachodniego jest możliwa do osiagnięcia, przynajmniej na poziomie kwestii najistotniejszych. Będzie ona jednak wynikiem wykazania się przez obie strony elastycznością, dobrą wolą i perspektywicznym spojrzeniem na przyszłość całej cywilizacji zachodniej.

\footnotetext{
${ }^{21}$ Fragment wywiadu z J.M. Barroso, Unia to my wszyscy, „Newsweek” ( 18. 11. 2007 ), s.44.

22 R.Kagan, Potęga i Raj. Ameryka i Europa w nowym porządku Świata, Warszawa 2003, s.9.

23 Ibidem, s.65.
} 


\section{Bibliografia}

Barber. B. 2004. Dżihad kontra McŚwiat, Warszawa.

Bierdiajew. M. 2002. Sens historii. Filozofia losu człowieka, Kęty 2002.

Fragment wywiadu z Barroso J.M, Unia to my wszyscy „Newsweek” (18.11.07)

Huntington S.P. 2003. Zderzenie cywilizacji i nowy ksztatt ładu światowego. Warszawa 2003.

Jean.C, Geopolityka, Wrocław.

Kagan. R. 2003. Potęga i Raj. Ameryka i Europa w nowym porządku Świata, Warszawa 2003.

Stosunki międzynarodowe, pod red. Malendowski. W. Mojsiewicz. Cz. 2004. Wrocław 2004.

Sobczak. J. 2002. Zmierzch cywilizacji, Poznań.

Spengler, 2001. O, Zmierzch Zachodu. Zarys morfologii historii uniwersalnej. Warszawa. 